\title{
ANALISIS PENGARUH KEPUASAN KERJA, IKLIM ORGANISASI KOMITMEN ORGANISASI TERHADAP EFEKTIVITAS ORGANISASI : ORGANIZATIONAL CITIZENSHIP BEHAVIOR (OCB) SEBAGAI MEDIASI
}

\author{
Muhammad Harri *) \\ *) Dosen Program Studi Manajemen FE UNKRIS \\ Alamat: Kampus UNKRIS, Jatiwaringin Jakarta Timur \\ Email : gigiharri12@ gmail.com
}

\begin{abstract}
This study aims to determine the influence of job satisfaction, organizational climate, organizational commitment and organizationa citizenship behavior on organizational effectiveness in PT. Cosmo Makmur Indonesia. Population and sample ini this study in the number of employee of 169 people. Analysis the data used was the validity and reliability test with path analysis. From the analysis, the coefficient of the determinan $\left(R^{2}\right)$ noted that organizational citizenship behavior influenced by job satisfaction, organizational climate, organizational commitment by $87 \%$ and the ramining $13 \%$ was influence by other factors which not included in the model. Job satisfaction significantly effect of 3.540, organizational climate siginificantly effect of 2,889 and organizational commitment significantly effect of 2,108 and organizational citizenship behavior significantly effect of 6.862. The analysis of the test, yhe coefficient of the determination noted that the organizational effectiveness was influenced by job satisfaction, organizational climate, organizational commitment, and organizational citizenship behavior..
\end{abstract}

Keywords: Job satisfaction, organizational climate, organizational commitment, organizational citizenship behavior and organizational effectiveness

\section{PENDAHULUAN}

Dalam meningkatkan mutu manajemen sumber daya manusia dalam suatu organisasi tentunya ada tantangan yang mempengaruhi efektifitas organisasi. Permasalahan yang sering muncul antara lain sistem informasi, perbedaan karakteristik individu dalam organisasi, iklim organisasi, system nilai manajer, kepuasan kerja karyawan, komitmen organisasi dan tuntutan organisasi. Pemecahan permasalahan tersebut perlu ada kajian yang mendalam untuk memperoleh sumber daya manusia yang berkualitas dan mampu bersaing sehingga tujuan dari organisasi akan tercapai dengan baik. Salah satu pendekatan yang sesuai adalah karyawan perlu memliki sikap dan prilaku organizational citizenship behavior.

William dan Anderson (2010) menyatakan bahwa organizational citizenship behavior dapat meningkatkan efesiensi dan efektivitas organisasi dengan memberikan kontribusi terhadap transformasi sumber daya, inovasi dan kemampuan beradaptasi. Perilaku ini dipengaruhi oleh faktor kepuasan kerja karyawan. Kepuasan kerja karyawan dipengharuhi oleh faktor internal atau dari dalam diri karyawan dan faktor eksternal di luar diri karyawan seperti jenis pekerjaan, gaji yang diberikan, kesempatan promosi yang adil, atasan 
yang bijaksana, rekan kerja yang mendukung yang akan mengjasilkan kepuasan karyawan yang berpengaruh pada pekerjaan yang dijalaninya.Selain kepuasan kerja karyawan komitmen organisasi dapat meningkatkan keterikatan karyawan pada organisasi. Untuk mendukung terciptanya organizationmal citizenship behavior perlu iklim organisasi yang nyaman dan menyenangkagt sehingga efektifitas organisasi dapat terwujud dengan baik

PT. Cosmo Makmur Indonesia terletak di Kabupaten Bogor Jawa Barat merupakan salah satu perusahaan yang memproduksi pachaging plastik. Yang memiliki kualitas yang baik. Dibalik seluruh proses produksi yang dihasilkan oleh PT. Cosmo Makmur Indonesia tidak luput dari pengelolaan sumber daya manusia yang tertata dengan baik. Prestasi PT . Cosmo Makmur Indonesia didukung oleh kinerja yang baik dari karyawannya. Namun demikian berdasarkan data kepegawaian masih terdapat karyawan yang kurang kinerjanya misalnya ketidakhadiran, Berdasarkan data tahun 2017 terdapat $10 \%$ ketidakhadiran dalam bekerja. Turnover pada enam bulan tahun terakhir 2017 mengindikasikan masalah dalam kepuasaan kerja karyawan terdapat 5\% . Hal ini diduga berdampak pada efektifitas kerja karyawan menurun dan berpengaruh pada efektifitas organisasi.

Indikasi masalah yang ada pada PT.Cosmo makmur Indonesia harus mampu merumuskan strategi dan solusi untuk menyelesaikan permasalahan. Oleh karena itu perlu dilakukan kajian yang mendalam atau penelitian tentang kepuasan kerja, iklim organisasi, komitment organisasi yang berpengaruh terhadap organizational citizenship behavior yang berpengaruh terhadap efektifitas organisasi.

\section{LANDASAN TEORI}

\section{Kepuasan Kerja}

Kepuasan Kerja adalah tingkat rasa puas individu bahwa mereka mendapat imbalan yang setimpal dari bermacam macam aspek situasi pekerjaan dari organisasi tempat mereka bekerja (Tangkilisan, 2005). Menurut Robbin (2003) kepuasan kerja adalah suatu sikap umum terhadap pekerjaan seseorang, selisih antara banyaknya ganjaran yang diterima seorang pekerja dan banyaknya yang mereka yakini yang seharusnya mereka terima. Menurut Luthans (2006) kepuasan kerja hasil dari persepsi karyawan mengenai seberapa baik pekerjaan mereka memberikan hal yang penting. Menurut Hasibuan (2007) berpendapat bahwa tolak ukur tingkat kepuasan kerja yang mutlak tidak ada karena setipa individu karyaswan berbeda standar kepuasan kerja hanya diukur dengan kedisiplinan, moral kerja, turnover kecil maka secara relatif kepuasan kerja karyasan baik begitu sebaliknya jika kedisiplinan, moral kerjabdan turover karyawan besar maka kepuasan kerja karyawan di perusahaan kurang, kepuasan kerja terdiri kedisiplinan, moral kerja dan turover.

Indikator kepuasan kerja terdiri dari pekerjaan itu sendiri, imbalan, kesempatan promosi, rekan kerja, kondisi kerja.

\section{Iklim Organisasi}

Wirawan (2007) menyatakan iklim organisasi adalah persepsi anggota organisasi (secara individual dan kelompok) dan mereka yang secara tetap berhubungan dengan organisasi misalnya pemasok, konsumen, konsultan dan kontraktor) menegnai yang ada atau yang terjadi di lingkungan internal organisasi secara rutin yang mempengaruhi sikap dan prilaku organisasi.

Indikator untuk mengukur iklim organisasi adalah: struktur standar, 
tanggungjawab, penghargaan, dukungan dan komitmen.

\section{Komitmen Organisasi}

Robbin (2003) mengemukakan salah satu sikap yang merefleksikan perasaan suka atau tidak suka terhadap organisasi tempat bekerja adalah komitmen organisasi. Menurut Schermerhorn, et al (2011) menyatakan bahwa komitmen organisasi adalah komitmen sebagai loyalitas seorang individu pada organisasi.

Komitmen organisasi didefinisikan sebagai keinginan pada sebagian pekerja untuk tetap menjadi anggota organisasi (Colquitt, et al, 2015). Menurut Newstrom, (2011) menyatakan bahwa komitmen organisasi merupakan ukuran tentang keinginan pekerja untuk tetap dalam perusahaan di masa depan.

Komitmen organisasi sebagai sebagai perasaan identifikasi, loyalitas, dan pelibatan pekerja terhadap organisasi (Gibson, Ivancevich, Donnely dan Konopaske (2012). Menurut Wibowo (2007) komitmen organisasi adalah perasaan, sikap dan prilaku individu mengidentifikasikan dirinya sebagai bagian dari organisasi, terlibat dalam proses kegiatan organisasi dalam mencapai tujuan organisasi.

Komitmen organisasi menurut Natalie Allen, et al (1997) adalah : (1) Affective commitment : terjadi apabila karyawan ingin menjadi bagian dari organisasi karena adanya ikatan emosional atau merasa mempunya nilai sama dengan organisasi. (2) Continuance commitment : kemauan individu untuk tetap bertahan dalam organisasi karena tidak menemukan pekerjaan lain atau reward tertentu. (3) Normative commitment : timbul dari nilai nilai karyawan, karyawan bertahan menjadi anggota organisasi karena ada kesadaran bahwa berkomitmen terhadap organisasi merupakan hal yang memang seharusnya dilakukan.
Indikator untuk mengukur komitmen organisasi adalah affective commitment, continuance commitment dan normative commitment.

\section{Organizational Citizenship Behavior}

Menurut Luthans (2006)

mengemukakan bahwa organizational citizenship behavior atau kewarganegaran organizational sangat terkenal dalam perilaku organisasi saat pertama kali diperkenalkan sekitar 20 tahu yang lalu dengan dasar teori disposiosi/ kepribadian dan sikap kerja. Dasar kepribadian untuk organizational citizenship behavior merefleksikan ciri/trait predisposisi karyawan yang kooperatif, suka menolong, perhatian dan bersungguh- sungguh, Sedangkan dasar sikap mengindikasikan bahwa karyawan terlibat dalam organizational citizenship behavior untuk membalas tindakan organisasi.Kesimpulannya organizational citizenship behavior merupakan perilaku organisasi yang mencakup faktor kepribadian dan sikap kerja senagai dasar utama, sebagai perilaku karyawan yang dengan suka rela bersedia melakukan hal hal di luar uaian jabatan formal yang menguntungkan organisasi, sehingga memberikan dampak bagi efektivitas organisasi.

Indikator untuk mengukur organizational citizenship behavior adalah altruism, courtesy, sportsmanship, civic virtue dan conscientiousness.

\section{Efektivitas Organisasi}

Menurut Jones (Mahmuddin Yasin dalam bukunya "Membangun Organisasi yang Berbudaya", 2012) efektifitas organisasi dapat terlaksana dengan baik tergantung dari peran seorang manajer yaitu : (1) Control : yaitu kemampuan untuk mengontrol lingkungan eksternal dan menarik sumber daya untuk kepentingan organisasi serta menarik pelanggan. (2) Innovation : yaitu kemampuann dan keterampilan 
organisasi untuk menemukan produk dan proses baru termasuk menciptkan struktur dan budaya organisasi baru yang dapat meningkatkan kemampuan perusahaan untuk berubah, beradaptasi dan berkembang. (3) Efficiancy, yaitu kemampuan untuk mengembangkan fasilitas produksi yang baru, teknologiteknologi yang baru yang dapat mendistribusikan produk secara tepat waktu dan biaya yang paling efesien termasuk penggunaan system informasi yang berbasis internet, total quality management dan just in time inventory system untuk meningkatkan produktivitas.

Georgopualos dan Tannebaum (2005) mendefinisikan efektifitas organisasi adalah tingkat sejauh mana organisasi berhasil memanfaatkan sumber daya yang ada seoptimal mungkin dalam usaha mencapai tujuan atau sasarannya dengan tetap menghindari ketegangan seminimal mungkin di antara para anggotanya. Efektivitas organisasi dapat dievaluasi melalui : (1) pencapaian sasaran dan (2) proses pelaksanaan organisasi, yang tercermin dalam prilaku organisasi (Hutapea dan Thoha, 2008).

Indikator untuk mengukur efektifitas organisasi melalui control, innovation, efficiency.

\section{Kerangka Penelitian}

Kerangka penelitian dapat dilihat dari Model sebagi berikut :

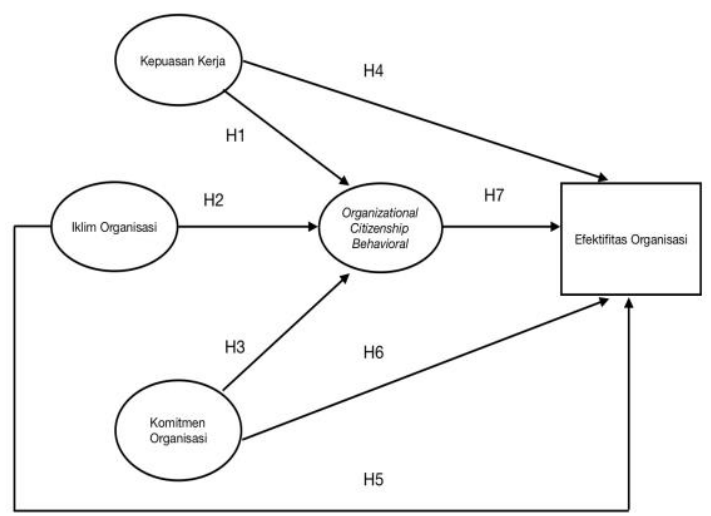

\section{Hipotesis}

H1 : Terdapat pengaruh positif dan signifikan kepuasan kerja terhadap organizational citizenship behavior

$\mathrm{H} 2$ : Terdapat pengaruh positif dan signifikan iklim organisasi terhadap organizational citizenship behavior

H3 : Terdapat pengaruh posiotif dan signifikan komitmen organisasi terhadap organizational citizenship behavior

H4 : Terdapat pengaruh positif dan signifikan kepuasan kerja terhadap efektifitas organisasi

H5 : Terdapat pengaruh positif dan signifikan iklim organisasi terhadap efektifitas organisasi

H6 : Terdapat pengaruh positif dan signifikan komitmen organisasi terhadap efektifitas organisasi

H7 : Terdapat pengaruh poistif dan signifikan organizational citizenship behavior terhadap efektifitas organisasi

\section{METODE PENELITIAN}

Subyek penelitian ini adalah karyawan PT. Cosmo Makmur Indonesia, sedangkan obyek penelitian adalah, kepuasan kerja, iklim organisasi, komitmen organisasi, organizational citizenship behavior dan efektivitas organisasi. Jumlah sampel penelitian 169 responden.

\section{Analisis Data \\ Analisis data menggunakan path (jalur) untuk mengukur variabel kepuasan kerja (X1), iklim organisasi (X2), komitmen organisasi (X3) terhadap efektivitas organisasi (Y2) melalui}


organizational citizenship behavior sebagai variabel mediasi (Y1).

\section{Instrumen Penelitian}

1. Kepuasan kerja indikatornya terdiri dari pekerjaan itu sendiri, imbalan, kesempatan promosi, rekan kerja, kondisi kerja.

2. Iklim organisasi indikatornya terdiri dari struktur, standar-standar, tanggung jawab,penghargaan, dukungan dan komitmen.

3. Komitmen Organisasi indikatornya terdiri Affective Commitment, Contonuance Commitment, Normative Commitment

4. Organizational Citizenship Behavior: Altruisme, Cortesy, Sprotsmanship, Civic Virtue, Conscienetousness

5. Efektivitas Organisasi: Control, Inovation, Eficiency

Kelima instrumen tersebut telah diuji validitas dan reliabilitasnya dengan menggunakan metode Splithalf dari Pearson (Subino, 1987 :123-126). Indeks reliabilitas perangkat kepuasan kerja diperoleh $\mathrm{r}=0,810$ dengan $\mathrm{t}=8,97$ signifikan pada tingkat 0,995 , instrumen iklim organisasi diperoleh harga $\mathrm{r}=$ 0,832 dengan $\mathrm{t}=8,97$ signifikan pada tingkat 0,995, instrumen komitmen organisasi diperoleh harga $\mathrm{r}=0,809$ dengan $\mathrm{t}=8,97$ signifikan pada tingkat 0,995, instrumen organizational citizenship behavior $(\mathrm{OCB})$ diperoleh $\mathrm{r}=$ 0,813 dengan $\mathrm{t}=8,97$ sedangkan instrumen efektifitas organisasi diperoleh $\mathrm{r}=0,855$ dengan $\mathrm{t}=8,97$.

\section{PEMBAHASAN}

H1 : Terdapat pengaruh positip dan signifikan kepuasan kerja terhadap organizational citizenship behavior Karyawan PT. Cosmo Makmur Indonesia
Hasil penelitian menunjukkan pengaruh yang sangat kuat positif dan signifikan antara kepuasan kerja dengan organizational citizenship behavior pada karyawan PT. Cosmo Makmur Indonesia yaitu t statistik sebesar 2, 791 dan t tabel sebesar 1,65. Hasil penelitian ini relevan dengan penelitian terdahulu yang dilakukan oleh Organi et.al (2006) menyatakan adanya korelasi yang positip antara kepuasan kerja dan organizational citizenship behavior, berarti karyawan yang memiliki kepuasan kerja yang tinggi maka organizational citizenship behavior pun semakin baik. Dalam teori yang dikemukan oleh Robbis (1996) menyatakan karyawan yang memiliki tingkat kepuasan kerja yang tinggi menunjukkan sikap yang positif terhadap pekerjaannya, sedangkan karyawan yang merasa tidak puas dengan pekerjaan menunjukkan sikap yang negatif dalam nekerja.

$\mathrm{H} 2$ : Terdapat pengaruh positif dan signifikan iklim organisasi terhadap organizational citizenship behavior Karyawan PT. Cosmo Makmur Indonesia

Hasil penelitian menunjukkan bahwa iklim organisasi berpengaruh positif dan signifikan terhadap organizational citizenship behavior, hal ini terlihat dari hasil $\mathrm{t}$ statistik yang lebih besar dari $t$ tabel yaitu 2,283 dan t tabel 1,65 pada karyawan PT. Cosmo Makmur Indonesia. Sesuai dengan hasil penelitian terdahulu oleh Brahmana dan Sofyan tahun 2007 yang menyatakan salah satu faktor yang mempengaruhi organizational citizenship behavior adalah iklim organisasi. Sesuai dengan teori yang dikemukakan oleh Organ (1988) menyatakan bahwa jika iklim, organisasi dipersepsikan secara positif maka individu sebagai anggota organisasi akan sukarela melaksanakan pekerjaan dalam organisasi melebihi apa yang diharapkan dan dilaksanakan. 
H3 : Terdapat pengaruh positif dan signifikan komitmen organisasi terhadap organizational citizenship behavior Karyawan PT. Cosmo Makmur Indonesia

Hasil penelitian menunjukkan komitmen organisasi berpengaruh positif dan signifikan terhadap organizational citizenship behavior, nilai t statistik 2,410 dan nilai $\mathrm{t}$ table 1,65. Hal ini berarti semakin tinggi komitmen organisasi maka semakin tinggi juga organizational citizenship behavior. Hasil penelitian terdahulu oleh Hasanbasri (2007) dan Kelana (2009) yang menyatakan bahwa komitmen organisasi berpengaruh positif dan signifikan dengan organizational citizenship behavior. Hasil penelitian ini sesuai dengan pendapat Schappe 1998 : Willian dan Anderson (Erthurk et,al 2004) menyatakan bahwa kecenderungan sikap karyawan terhadap komitmen organisasi sebagai faktor utama yang mempengaruhi kemunculan organizational citizenship behavior. Secara empirik apabila karyawan menunjukkan suatu keinginan bertahan dalam organisasi dan merasakan keterikatan secara emosional maka akan memiliki komitmen.

H4 : Terdapat pengaruh positif dan signifikan kepuasan kerja terhadap efektivitas organisasi pada PT. Cosmo Makmur Indonesia.

Dari hasil penelitian menunjukkan kepuasan kerja berpengaruh positif dan signifikan terhadap efektifitas organisasi , terlihat dari hasil t-statistik lebih besar dari t- tabel, t- statistik diperoleh 3, 540 dan t-tabel sebesar 1,65. Hasil penelitian ini sesuai dengan peneliti terdahulu yaitu Soedjono (2005) yang menyatakan bahwa terdapat hubungan yang positif antara kepuasan kerja dengan efektifitas organisasi.Penelitian ini membuktikan bahwa semakin tinggi kepuasan kerja karyawan maka akan semakin tinggi pula efektifitas organisasinya.
H5 : Pengaruh iklim organisasi terhadap efektivitas organisasi karyawan PT Cosmo Makmur Indonesia

Hasil penelitian menunjukkan iklim organisasi berpengaruh positif dan signifikan antara iklim organisasi dengan efektifitas organisasi dengan diperoleh hasil t-statistik yaitu 2,889 lebih besar dari $t$ tabel sebesar 1,67. Penelitian ini sesuai dengan Gie (2002) yang mengemukkan bahwa efektifitas adalah keadaan dan kemampuan suatu kerja yang efektivitas adalah keadaan atau kemampuan suatu kerja yang dilaksanakan oleh manusia untuk memberikan manfaat yang diharapkan.Oleh karena itu hubungan antara iklim organisasi dengan efektivias organisasi memiliki keterkaitan yang signifikan, iklim organisasi yang kondusif dapat mendukung atau menjadi kunci keberhasilan suatu organisasi dalam mencapai tujuan.

H6: Pengaruh komitmen organisasi terhadap efektivitas organisasi pada PT. Cosmo Makmur Indonesia.

Dari hasil penelitian diketahui bahwa komitmen organisasi berpengaruh positif dan signifikan terhadap efektifitas organisasi dengan hasil t statistik sebesar 2,108 dan $t$ tabel 1,65. Hasil penelitian ini sesuai dengan penelitian terdahulu yang dilakukan oleh Ivancevich dan Matteson (2002), Chow dan Holden (1997) yang menyimpulkan bahwa jika tidak ada komitmen maka dapat mengurangi efektifitas organisasi. Sesuai dengan pendapat Kuntjoro (2009) menyatakan bahwa komitmen organisasi yang kuat dapat dibentuk dan dihasilkan dari berbagai faktor yaitu faktor personal seperti usia, lamanya bekerja, serta faktor kepribadian dan lainnya. Selain itu terdapat juga faktor organisasi seperti pengalaman kerja tujuan organisasi yang konsisten akan memunculkan sikap tanggungjawab terhadap organisasi. 
H7 : Pengaruh organizational citizenship behavior terhadap efektivitas organisasi pada PT. Cosmo Makmur Indonesia.

Dari hasil penelitian menunjukkan pengaruh yangh positif dan signifikan organizational citizenship behavior terhadap efektivitas organisasi dengan diperoleh hasil t-statistik sebesar 6,862 dengan t-tabel sebesar 1,65. Sesuai dengan hasil penelitian yang dilakukan oleh Organ (1988) bahwa organizational citizenship behavior secara eksplisitb dapat dikenal dengan system kerja formal yang secara keseluruhan mampu meningkatkan efektivitas organisasi. PT. Cosmo Makmur Indonesia sangat tergantung pada usaha karyawan terutama kesediaan secara sukarela bekerja melebihi tanggungjawab formalnya. Penelitian Ariani (2008) menyatakan bahwa organizational citizenship behavior merupakan perilaku positif di tempat kerja yang mendukung kinerja individu dan kefektivitasan organisasi. PT. Cosmo Makmur Indonesia dalam seleksi karyawan mengutamakan karyawan yang memiliki kepribadian yang positif yang lebih mementingkan organisasi atau perusahaan sehingga dapat membentuk lingkungan kerja yang kondusif yang mendorong organizational citizenship behavior dalam semua kegiatan.

\section{KESIMPULAN DAN SARAN}

\section{Kesimpulan}

1. Kepuasan kerja berpengaruh positif dan signifikan terhadap organizational citizenship behavior.

2. Iklim organisasi berpengaruh positif dan signifikan terhadap organizational citizenship behavior

3. Komitmen organisasi berpengaruh positif dan signifikan terhadap organizational citizenship behavior.
4. Kepuasan kerja berpengaruh positif dan signifikan terhadap efektivitas organisasi.

5. Iklim organisasi berpengaruh positif dan signifikan terhadap efektivitas organisasi

6. Komitmen organisasi berpengaruh positif dan signifikan terhadap efektivitas organisasi.

7. Organizational citizenship behavior berpengaruh positif dan signifikan terhadap efektivitas organisasi.

8. Organizational citizenship behavior menjadi variabel mediasi yang mempunyai efek atau pengaruh yang signifikan antara kepuasan kerja terhadap efektivitas organisasi.

9. Organizational citizenship behavior menjadi variabel mediasi yang mempunyai efek atau pengaruh yang signifikan antara iklim organisasi 2,844 terhadap efektivitas organisasi, sebesar 144 dan nilai tidak langsung dengan organizational citizenship behavior sebagi variabel intervening dengan nilai koefisien sebesar 1,092.

10. Organizational citizenship behavior menjadi variabel mediasi yang mempunyai efek atau pengaruh yang signifikan antara komitmen organisasi terhadap efektivitas organisasi, sebesar 0,697 dan nilai tidak langsung dengan organizational citizenship behavior sebagi variabel intervening dengan nilai koefisien sebesar 1,126.

\section{SARAN}

1. Dalam upaya meningkatkan kepuasan kerja karyawan pada PT. Cosmo Makmur Indonesia sebaiknya lebih meningkatkan kesejahteraan karyawan dan memberikan akses untuk promosi dan dukungan dari pimpinan sebagai motivator. 
2. Dalam upaya meningkatkan komitmen organisasi mka pimpinan harus mampu menumbuhkan rasa tanggung jawab dari karyawanan dan memberikan kepercayaan dalam pekerjaannya, memberikan aspirasi dan ide yang baik pada karyawan, pertlu adanya persamaan persepsi antara karyawan dan pimpinan

3. Dalam upaya meningkatkan organizational citizenship behavior (OCB) pada PT. Cosmo Makmur Indonesia perlu dilakukan langkah antara lain adanya sosialisasi visi, misi dan tujuan organisasi dan nilai nilai perusahaan yang jelas dalam upaya pencapaian tujuan dengan kegiatan yang berkesinambungan, sebaiknya perusahaan memnberikan reward bagi karyawan yang berprestassi dan punishment bagi karyawan yang malas, adanya keterbukaan antara atasan dan bawahan, memberikan kesempatan pada karyawan untuk meningkatkan kompetensinya melalui pendidikan dan pelatihan sehingga karyawan dapat memberikan kontribusi yang maksimal pada perusahaan.

\section{DAFTAR PUSTAKA}

Allen, N.J., and Mayer, J.P., (1990), The Measurment and Antecedents of Affective, Continuance and Normative Commitment to the Organization, Journal of Occupational Psychology, No. 63: 1-18.

Armstrong, Michael. (2000). The art of $H k D$.Vol 2, Crest Publishing House: New Delhi

Dessler, G (2010). Human Resources Management. London: Prenticehall International Inc.

Ghozali, I (2006). Structural Equation Modeling, Metode Alternatif dengan Partial Least Square.

Badan Penerbit Universitas Diponegoro: Semarang.

Greenberg, J., Baron, R.A. (2003), Behavior in Organizations

Understanding and Managing the Human Side of Work. New Jersey: Prentice-Hall International Griffin.

R.W. (2004), Management, 7th edition, Massachusetts: Houghton Mifflin Company

Hutapea, Parulian dan Nurianna Thoha. (2008). Kompetensi Plus. Jakarta: PT Gramedia Pustaka Utama Iskandar.

Krietner, R. \& Kinicki, R (2004), Organizational Behavior, 6th edition, McGrawHill Kuntjoro, Zainudin, S. (2009). Komitmen Organisasi.

http://www.epsikologi.com/epsi/sea rch.as p Litwin GH, Stringer RA Jr. 1968. Motivation and organizational climate. Boston: Harvard University Press.

Mahendra, Rully (2009), Pengaruh Kepuasan Kerja, Komitmen Organisasi dan Lingkungan Kerja terhadap Organizational Citizenship Behavior (OCB) Pegawai Bagian Umum Kantor Sekretariat Daerah Kabupaten Semarang.

Mahmudidin Yasin, 2013, Membangun Organisasi Berbudaya, Jakarta, PT. Publikasi

Moeljono, Djokosantoso. 2003. Budaya Korporat dan Keunggulan Korporasi. PT Elex Media Komputindo. Jakarta. Muchinsky,

Paul M. (1993). Psychologt applied to work.76 edition. USA: Thomson Wadsworth. 
Robbins, S. \& Judge, T. (2007). Organizational Behavior. 12 th edition.

Prentice Hall Robbins S.P. (2008). Perilaku Organisasi: Konsep, Kontroversi, Aplikasi, edisi kedelapan versi Bahasa Indonesia, Jilid 1 \& 2 , PT Prenhallindo: Jakarta.

Tangkilisan, Hessel Nogi S. (2005).Manajemen Publik. Grasindo, Jakarta. Triton, P.B. 2006. SPSS 13.0 Tarapan: Reset Statistik Parametrik. Yogyakarta: Andi Offset.

Organ, D.W. \& Konovsky, Mary (1988), Cognitive Versus Affective Determinants of Organizational Citizenship Behavior, Journal of Applied Psychology, Vol 74. No 1.

Organ, D. W., and Ryan, K. (1994), A Meta- analytic Review of Attitudinal and Dispositional Predictors of Organizational Citizenship Behavior, Personnel Psychology, Vol. 48.

Sekaran, U (2003), Reseach Methods for Bussiness: a Skill Building Approach, John Wiley and Sons, New York

SeniatiL. (2006). Pengaruh Masa Kerja, Trait Kepribadian, Kepuasan Kerja, dan Iklim Psikologis Terhadap Komitmen Dosen pada Universitas Indonesia. Makara Sosial Humaniora Journal. 10: 88-97.

Sloat, Kim C (1999), Organizational Citizenship: Does Your Firm Inspire Employees To Be "Good Citizens"?, Profesional Safety. April Sugiyono. 2010. Statistika untuk Penelitian. Bandung: Alfabeta.

Wexley dan Gary A. Yukl, (1992), Organizational Behaviour and Personnel Psychology, Penerjemah Muh. Shobaruddin. Jakarta: Rineka Cipta.

Wexley Kenneth $\mathrm{N}$ and Yukl Gary A. 1992. Perilaku Organisasi dan Psikologi Personalia. terjemahan Muh. Shobaruddin, Jakarta: Rineka Cipta.

William, Larry J. And Anderson, Stella E. (1991), Job Satisfaction and Organizational Commitment as Predictors of Organizational Citizenship and In-Role Behaviors, Journal of Management, September 1991 17:601-617

Wirawan. (2007). Budaya dan Iklim Organisasi Teori Aplikasi dan Penelitian. Ed.1. Jakarta: Salemba Empat. 
